\title{
NUCLEAR REGULATORY COMMISSION ISSUANCES
}

\author{
August 1997
}

This report includes the issuances received during the specified period from the Commission (CLI), the Atomic Safety and Licensing Boards (LBP), the Administrative Law Judges (ALJ), the Directors' Decisions (DD), and the Decisions on Petitions for Rulemaking (DPRM)

The summaries and headnotes preceding the opinions reported herein are not to be deemed a part of those opinions or have any independent legal significance.

\section{U.S. NUCLEAR REGULATORY COMMISSION}

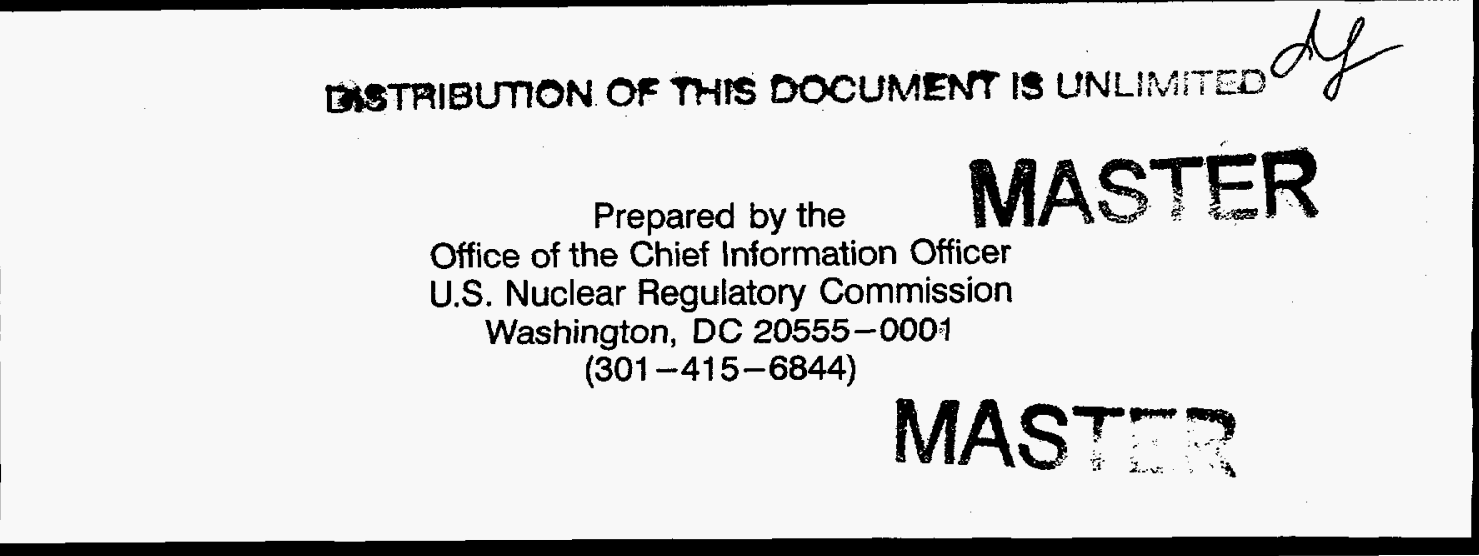




\section{COMMISSIONERS}

Shirley A. Jackson, Chairman

Greta J. Dicus

Nils J. Diaz

Edward McGaffigan, Jr.

B. Paul Cotter, Jr., Chief Administrative Judge, Atomic Safety \& Licensing Board Panel 


\section{DISCLAIMER}

Portions of this document may be illegible electronic image products. Images are produced from the best available original document. 


\section{CONTENTS}

Issuances of the Nuclear Regulatory Commission

\section{ATLAS CORPORATION}

(Moab, Utah Facility)

Docket 40-3453-MLA

MEMORANDUM AND ORDER, CLI-97-8, August 4, 1997

INTERNATIONAL URANIUM (USA) CORPORATION

(White Mesa Uranium Mill)

Docket 40-8681-MLA (Alternate Feed Material)

MEMORANDUM AND ORDER, CLI-97-9, August 7, 1997

RALPH L. TETRICK

(Denial of Application for Reactor Operator License)

Docket 55-20726-SP

MEMORANDUM AND ORDER, CLI-97-10, August 7, 1997

\section{Issuance of Director's Decision}

\section{NORTHERN STATES POWER COMPANY}

(Prairie Island Nuclear Generating Plant;

Prairie Island Independent Spent Fuel Storage Installation)

Dockets 50-282, 50-306, 72-10

DIRECTOR'S DECISION UNDER 10 C.F.R. $\$ 2.206$,

DD-97-18, August 29, 1997 


\section{Commission Issuances}

$\frac{Z}{0}$ 
UNITED STATES OF AMERICA

NUCLEAR REGULATORY COMMISSION

COMMISSIONERS:

Shirley Ann Jackson, Chairman

Greta J. Dicus

Nils J. Diaz

Edward McGaffigan, Jr.

In the Matter of

Docket No. 40-3453-MLA

ATLAS CORPORATION

(Moab, Utah Facility)

August 4, 1997

The Commission concluded that the Petitioner for intervention had failed to demonstrate standing. The Commission therefore denied his appeal of the Presiding Officer's order denying his petition to intervene.

\section{COMMISSION PROCEEDINGS: APPELLATE REVIEW}

\section{RULES OF PRACTICE: STANDING}

The Commission ordinarily defers to Licensing Board standing determinations, and sees no legal error or abuse of discretion in the Presiding Officer's refusal to grant standing to a Petitioner to intervene, given his failure to offer more than general responses to the Presiding Officer's reasonable and clearly articulated requests for more specific information about his proximity-based standing claims. The four opportunities that the Petitioner had to specify his claims were entirely adequate.

\section{MEMORANDUM AND ORDER}

The Commission denies the appeal filed by Mr. John F. Darke June 2, 1997, and affirms the Presiding Officer's order, LBP-97-9, 45 NRC 414 (1997). We 
do so on the grounds set forth in LBP-97-9. In that order, the Presiding Officer rejected Mr. Darke's request for a formal hearing, concluded that Mr. Darke had not met his burden to establish standing to intervene, and dismissed the proceeding.

We ordinarily defer to Licensing Board standing determinations. See Yankee Atomic Electric Co. (Yankee Nuclear Power Station), CLI-96-7, 43 NRC 235, 248 (1996). Here, we see no legal error or abuse of discretion in the Presiding Officer's refusal to grant standing to Mr. Darke, given his failure to offer more than general responses to the Presiding Officer's reasonable and clearly articulated requests for more specific information about Mr. Darke's proximitybased standing claims. The four opportunities that Mr. Darke had to specify his claims were entirely adequate.

IT IS SO ORDERED.

For the Commission

JOHN C. HOYLE

Secretary of the Commission

Dated at Rockville, Maryland,

this 4th day of August 1997. 
UNITED STATES OF AMERICA

NUCLEAR REGULATORY COMMISSION

COMMISSIONERS:

Shirley Ann Jackson, Chairman

Greta J. Dicus

Nils J. Diaz

Edward McGaffigan, Jr.

In the Matter of

INTERNATIONAL URANIUM (USA)

CORPORATION

(White Mesa Uranium Mill)
Docket No. 40-8681-MLA

(Alternate Feed Material)

In response to a letter that included (1) an appeal of a Presiding Officer's decision denying Petitioners standing, (2) moving for reconsideration of the decision, and (3) moving to reopen the record, the Commission instructs the Presiding Officer to pass upon the two motions. The Commission concludes that the Presiding Officer's greater familiarity with the prior proceeding and pleadings in this case rendered him better equipped than the Commission to make prompt initial rulings on the merits of the two motions.

\section{COMMISSION PROCEEDINGS: APPELLATE REVIEW}

RULES OF PRACTICE: APPELLATE FILINGS; APPELLATE REVIEW (INTERVENTION DENIALS); LICENSING BOARDS; MOTION FOR RECONSIDERATION; MOTION TO REOPEN RECORD; RECONSIDERATION PETITIONS

The Commission disapproves of the practice of simultaneously seeking reconsideration of a Presiding Officer's decision and filing an appeal of the same ruling, because taking that approach would call for rulings on the same issues at the same time from both a trial and appellate forum. 
LICENSING BOARDS: JURISDICTION

\section{ADJUDICATORY BOARDS: JURISDICTION}

\section{RULES OF PRACTICE: APPELLATE FILINGS; APPELLATE REVIEW (INTERVENTION DENIALS); JURISDICTION (LICENSING BOARDS, PRESIDING OFFICER); LICENSING BOARDS; MOTION FOR RECONSIDERATION; MOTION TO REOPEN RECORD; RECONSIDERATION PETITIONS}

Because the Presiding Officer's greater familiarity with the prior proceeding and pleadings in this case renders him better equipped than the Commission to make prompt initial rulings on the merits of the motions for reconsideration and reopening of the record, the Commission instructs him to pass upon those motions, notwithstanding the pendency of the appeal.

\section{MEMORANDUM AND ORDER}

On July 30,1997 , three Petitioners jointly submitted a letter to Chairman Jackson' styled as an "appeal" of the Presiding Officer's order (LBP-97-12, 46 NRC 1 (1997)) rejecting their claims of standing. The same letter also asked the Presiding Officer to reconsider his decision and to reopen the record.

The Commission disapproves of the practice of simultaneously seeking reconsideration of a Presiding Officer's decision and filing an appeal of the same ruling, Houston Lighting and Power Co. (Allens Creek Nuclear Generating Station, Unit 1), ALAB-630, 13 NRC 84, 85 (1981), because taking that approach would call for rulings on the same issues at the same time from both a trial and appellate forum.

Here, the Presiding Officer's greater familiarity with the prior proceeding and pleadings in this case renders him better equipped than the Commission to make prompt initial rulings on the merits of the motions for reconsideration and reopening of the record. See Curators of the University of Missouri, CLI-95-1, 41 NRC 71, 94 (1995). We therefore instruct him to pass upon the two motions on their merits expeditiously, notwithstanding the pendency of the appeal. See Portland General Electric Co. (Trojan Nuclear Plant), ALAB-627, 13 NRC 20, 21 n.6 (1981). We will take appropriate action on the appeal after the Presiding

\footnotetext{
${ }^{1}$ Along with this Order, we are serving copies of the appeal letter on the Presiding Officer and on the other parties to the adjudication. All pleadings in Cormmission adjudications, even in informal Subpart $L$ proceedings, must be accompanied by an appropriate certificate of service. See 10 C.F.R. $\$ \$ 2.1203(\mathrm{e}), 2.712$. This letter contained no certificate of service and apparently was not actually served. We caution the parties to pay heed to the certificate-of-service requirements in the future.
} 
Officer decides whether to grant or deny the requests for reconsideration and reopening.

IT IS SO ORDERED.

For the Commission

JOHN C. HOYLE

Secretary of the Commission

Dated at Rockville, Maryland, this 7th day of August 1997. 
UNITED STATES OF AMERICA

NUCLEAR REGULATORY COMMISSION

COMMISSIONERS:

Shirley Ann Jackson, Chairman

Greta J. Dicus

Nils J. Diaz

Edward McGaffigan, Jr.

In the Matter of

Docket No. 55-20726-SP

\author{
RALPH L. TETRICK \\ (Denial of Application for Reactor \\ Operator License)
}

August 7, 1997

The Commission grants the NRC Staff's Petition for Review and reverses the Presiding Officer's decision requiring issuance of a Senior Reactor Operator (SRO) license. The Commission disagrees with the Presiding Officer's conclusions that the NRC Staff should have anticipated the need to offer evidence and arguments on the issue whether the candidate's SRO examination score should be rounded up to a passing grade of $80 \%$, and that the Staff's failure to anticipate this need precludes their raising such arguments and evidence on reconsideration. The Commission also disagreed with the Presiding Officer's decision to round up the SRO examination score, but agreed with him that the candidate had incorrectly answered Question 63 of the examination.

\title{
TECHNICAL ISSUES DISCUSSED: SENIOR REACTOR OPERATOR EXAMINATION (ROUNDING OF GRADE)
}

Although the Staff could reasonably have anticipated both that he might rule in the SRO candidate's favor on one of the exam questions and that such a ruling would raise his score to either a 79.59 (question deleted) or 79.80 (question graded in candidate's favor), the Staff need not have further anticipated that the Presiding Officer would then round the revised score upward to the next integer. 

EXAMINATION (ROUNDING OF GRADE)

\section{REGULATORY GUIDES: APPLICATION}

The version of NUREG-1021 in effect at the time the candidate took his exam did not address rounding directly but did state that a successful applicant must answer correctly "at least 80 percent" of the questions on the written examination. The phrase "at least" on its face suggests strongly that $80 \%$ is the minimal acceptable score and that rounding up lower scores is impermissible.

\section{TECHNICAL ISSUES DISCUSSED: SENIOR REACTOR OPERATOR EXAMINATION (ROUNDING OF GRADE)}

\section{AGENCY PRACTICE}

Agency practice is one indicator of how an agency interprets its regulations. Given that the Staff itself set the $80 \%$ threshold in the first place, the Commission is disinclined to disturb its consistently held view.

\section{TECHNICAL ISSUES DISCUSSED: SENIOR REACTOR OPERATOR EXAMINATION (ROUNDING OF GRADE)}

\section{REGULATORY GUIDES: APPLICATION}

The NRC's recent revision of NUREG-1021 to replace the minimum passing grade of " 80 percent" with " 80.00 percent" does not support an implication that the former term permitted rounding and therefore needed correction. Rather, the revision was akin both to the clarifying regulatory amendments that the Commission and other agencies regularly promulgate and to the clarifying legislation that Congress regularly enacts.

\section{LICENSING BOARDS: SCOPE OF REVIEW; REVIEW OF NRC STAFF'S ACTIONS; RESPONSIBILITIES}

\section{ADJUDICATORY BOARDS: ROLE}

\section{REGULATORY GUIDES: APPLICATION}

\section{SENIOR OPERATOR LICENSE: SCOPE OF INQUIRY}

The decision whether to round up near-passing scores requires a policy choice. Either option is plausible. Here, in the adjudicatory setting, the Commission declines to set aside the NRC Staff's policy judgment, supported by the language of NUREG-1021, to draw the pass-fail line at $80 \%$ minimum, 
without rounding up. When the Presiding Officer ordered rounding up on the ground that the SRO written examinations are not so precise that tenths of a percent have any meaning and essentially reduced the passing score from $80 \%$ to $79.5 \%$, he stepped into a Staff area of responsibility.

\section{MEMORANDUM AND ORDER}

On February 28, 1997, the Presiding Officer issued an Initial Decision in this proceeding concluding that Ralph $\mathrm{L}$. Tetrick, who is currently a reactor operator at the Turkey Point Nuclear Generating Plant (Units 3 and 4), had answered correctly seventy-eight out of ninety-eight valid questions on his Senior Reactor Operator (SRO) written examination. As a result of this ruling, the Presiding Officer revised Mr. Tetrick's score upwards to $79.59 \%$. The Presiding Officer then rounded Mr. Tetrick's revised score upwards still further - to the nearest integer, 80 - thereby giving him a passing grade on the written examination. LBP-97-2, 45 NRC 51, reconsideration denied, LBP-97-6, 45 NRC 130 (1997). The Presiding Officer accordingly ordered issuance of an SRO license to $\mathrm{Mr}$. Tetrick. The NRC Staff has filed a petition for review seeking Commission reversal of the Presiding Officer's decision.

Mr. Tetrick, in addition to supporting the Presiding Officer's ruling on the "rounding" issue, also asserts as an alternative ground for affirmance that he should be given credit for a correct answer to Question 63 of the written SRO examination. ${ }^{1}$ (The Presiding Officer had found that Mr. Tetrick's answer was incorrect. See $45 \mathrm{NRC}$ at 53-55.) Recently, because of new information submitted to the Commission, we remanded the Question 63 issue for further consideration by the Presiding Officer. CLI-97-5, 45 NRC 355 (1997). On remand, the Presiding Officer issued a Memorandum and Order again concluding that Mr. Tetrick's answer to Question 63 was incorrect. LBP-97-11, 45 NRC 441 (1997).

For the reasons set forth below, we agree with the Staff's positions regarding both the rounding issue and Question 63. We therefore grant the Staff's petition for review and reverse the Presiding Officer's decision requiring the Staff to issue Mr. Tetrick an SRO license. ${ }^{2}$

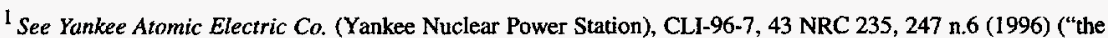
prevailing party below [may] argue any ground that would defend the ultimate result reached by the Board including arguments that the Board had rejected").

${ }^{2}$ In our view, our disposition of this case would not benefit from requiring full briefing.
} 


\section{BACKGROUND}

Pursuant to Part 55 of our regulations, an applicant for an SRO license must pass both a written and an operating examination. The passing score for the written examination is $80 \%$. "Operator Licensing Examiner Standards," NUREG-1021. Mr. Tetrick passed the operating exam but received an initial score of only $78 \%$ on his 100 -question written test, taken on June 14, 1996.

On July 30, 1996, he sought an informal Staff review of his score on the latter exam, challenging the grading of four questions. On September 12, 1996, the Staff upheld the grading of three contested questions but agreed with Mr. Tetrick that the fourth was invalid and should be deleted. The Staff therefore raised Mr. Tetrick's score to $78.8 \%$ (seventy-eight out of ninety-nine).

On September 25, 1996, Mr. Tetrick sought a hearing before a Presiding Officer. Mr. Tetrick continued to challenge the grading of the remaining three questions, and also contested the scoring of another question. Following an informal hearing under 10 C.F.R. Part 2, Subpart L, the Presiding Officer issued LBP-97-2, ruling that one of the challenged questions (Number 96) was ambiguous and should be stricken from the written examination, but holding that Mr. Tetrick's answer to the other three challenged questions (Numbers 63, 84 , and 90) were indeed incorrect. $45 \mathrm{NRC}$ at 53-58.

This ruling had the effect of raising Mr. Tetrick's score to $79.59 \%$ (seventyeight out of ninety-eight questions). Because the Presiding Officer concluded that the written SRO tests were "not so precise that tenths of a percent have any meaning," he rounded Mr. Tetrick's revised score of 79.59 to the nearest integer, 80 , thereby giving him a passing grade on the written examination. LBP-97-2, $45 \mathrm{NRC}$ at 60.

On March 10, 1997, the Staff sought reconsideration of the Initial Decision. The Staff challenged the Presiding Officer's authority to round up Mr. Tetrick's score and submitted supportive evidence showing a Staff practice not to round scores upward to the nearest integer.

On March 27, 1997, the Presiding Officer denied the Staff's request on the ground that the Staff had improperly raised an argument based on evidence that the Staff could have (but had not) submitted during the hearing stage of the proceeding. According to the Presiding Officer, the Staff should have anticipated the possibility that he would rule in Mr. Tetrick's favor regarding one of the four contested questions and that the rounding issue would therefore arise. In justifying his prior ruling regarding rounding, the Presiding Officer explained that the Staff's recent amendment of NUREG-1021 to require a passing score of " 80.00 percent" rather than simply " 80 percent" was not yet in effect at the time Mr. Tetrick took his written exam, and that there was no other published guidance concerning either the number of significant digits in an examination 
score, or whether and how the score should be rounded. LBP-97-6, 45 NRC 130, 131-32 (1997).

The Staff filed with the Commission both a request for stay and a petition for review of the Presiding Officer's rulings in LBP-97-2 and LBP-97-6 on the rounding issue. Responding to the Staff's petition for review, Mr. Tetrick asserted that, if the Commission were to review the Presiding Officer's decisions on the rounding issue, it should also examine whether the Presiding Officer was correct in ruling that Mr. Tetrick had incorrectly answered Question 63 of the written SRO examination.

Shortly thereafter, the Staff submitted to the Commission a May 1, 1997 letter in which Mr. R.J. Hovey, the utility's Vice-President at Turkey Point stated his belief that Mr. Tetrick's answer to Question 63 was a correct one. The Staff, however, continued to maintain otherwise.

The Commission concluded in CLI-97-5, supra, that the Question 63 issue appeared to turn ultimately on the interpretation of language in a number of technical documents, some of which might not be in the record. The Commission therefore remanded the issue to the Presiding Officer and directed him to reconsider his prior ruling. The Commission also retained jurisdiction over the Staff's petition for review of the Presiding Officer's rulings on the rounding issue; deferred ruling on that issue; and granted a temporary stay of LBP-97-2 and LBP-97-6.

On remand, the Presiding Officer sought further information from the parties (May 27, 1997 unpublished order) and, based on that information, issued LBP-97-11, supra, reaffirming his earlier determination that Mr. Tetrick had incorrectly answered Question 63. The Presiding Officer reasoned that Mr. Hovey's support of Mr. Tetrick's answer was based on the erroneous assumption that the question posited only one annunciator. The Presiding Officer also found that Mr. Tetrick's proposed verification of the two consistent annunciators was unnecessary, given that they verified each other. In addition, the Presiding Officer was influenced by Mr. Tetrick's failure to respond directly to the questions regarding what specific steps Mr. Tetrick would take to verify the validity of the alarms and what would persuade him not to take the required IMMEDIATE ACTION after he had taken those steps. $45 \mathrm{NRC}$ at 445-47.

The case is now back before the Commission to decide the Staff's petition for review challenging the Presiding Officer's decision that Mr. Tetrick should receive his SRO license.

\section{DISCUSSION}

We are faced with three issues in this proceeding: (1) whether the Presiding Officer erred in concluding that the Staff's failure to present its rounding 
arguments at the hearing bars it from raising it on reconsideration; (2) if so, is the Staff's argument on rounding correct; and (3) is the Presiding Officer correct that Mr. Tetrick incorrectly answered Question 63. We answer all three questions "yes."

\section{A. The "Rounding" Issues}

We cannot accept the Presiding Officer's conclusion that the Staff should have anticipated at the hearing that it would need to present its evidence and arguments on the rounding issue. Although we agree with the Presiding Officer that the Staff could reasonably have anticipated both that he might rule in $\mathrm{Mr}$. Tetrick's favor on one of the exam questions and that such a ruling would raise his score to either a 79.59 (question deleted) or 79.80 (question graded in $\mathrm{Mr}$. Tetrick's favor), we see no reason why the Staff should have further anticipated that the Presiding Officer would then round the revised score upward to the next integer.

The version of NUREG-1021 in effect at the time Mr. Tetrick took his exam (Revision 7, Supp. 1 (June 1994)) did not address rounding directly but did state that a successful applicant must answer correctly "at least 80 percent" of the questions on the written examination. ${ }^{3}$ We believe that the phrase "at least" on its face suggests strongly that $80 \%$ is the minimal acceptable score and that rounding up lower scores is impermissible. Our conclusion is supported by the Oxford English Dictionary which defines this two-word phrase as "a qualifying phrase, attached to a quantitative designation to indicate that the amount is the smallest admissible."4 See also Webster's Third New International Dictionary (G.\&C. Merriam Co. 1976) at 1287 ("at least" means "at the lowest estimate").

The Staff's consistent prior practice confirms our understanding of the "at least 80 percent" standard. The Staff has refused in the past to "round up" almost-passing scores and has considered the $80 \%$ cutoff score as the grade below which a candidate will not pass the written exam. "Agency practice, of course, is one indicator of how an agency interprets its regulations." Yankee Atomic Electric Co. (Yankee Nuclear Power Station), CLI-96-6, 43 NRC 123,

\footnotetext{
${ }^{3}$ NUREG-1021 (Revision 7, Supp. 1, June 1994), Examiner Standards (ES) 401 at 6 of 7 (Form ES-401).

${ }^{4}$ The Compact Edition of the Oxford English Dictionary, Vol. I, Letter L, p. 160, col. 2 (Oxford Univ. Press 1979) (emphasis added). Other portions of the same version of NUREG-1021 use the synonym phrase " 80 percent or greater." See ES-401 at 1 of 7; ES-402 at 5 of 6; ES-501 at 3 of 24 . We construe this quoted phrase to have a meaning identical to "at least 80 percent."

${ }^{5}$ See Staff's Request for Stay, dated April 11, 1997, at 4 and supporting evidence cited therein (including three other recent instances in which the Staff refused to license an applicant with a written exam score between 79.50 and 80.00 ).
} 
129 (1996). Given that the Staff itself set the $80 \%$ threshold in the first place, ${ }^{6}$ we are disinclined to disturb its consistently held view.?

At bottom, the decision whether to round up near-passing scores requires a policy choice. Either option is plausible. Here, in the adjudicatory setting, we decline to set aside the NRC Staff's policy judgment, supported by the language of NUREG-1021, to draw the pass-fail line at $80 \%$ minimum, without rounding up. Cf. Rockwell International Corp. (Rocketdyne Division), ALAB925, 30 NRC 709, 722 n.15 (1989), aff'd, CLI-90-5, 31 NRC 337 (1990). In our view, when the Presiding Officer ordered rounding up on the ground that the SRO written examinations "are not so precise that tenths of a percent have any meaning" (LBP-97-2, $45 \mathrm{NRC}$ at 60) and essentially reduced the passing score from $80 \%$ to $79.5 \%$, he stepped into a Staff area of responsibility. ${ }^{8}$

\section{B. Question 63}

Mr. Tetrick raises with the Commission the issue whether he correctly answered Question 63 of his written SRO examination. That question read as follows:

Plant conditions:

- Preparations are being made for refueling operations

- The refueling cavity is filled with the transfer tube gate valve open.

- Alarm annunciators H-1/1, SFP LO LEVEL and G-9/5, CNTMT SUMP HI LEVEL are in alarm.

Which ONE of the following is the required IMMEDIATE ACTION in response to these conditions?

\footnotetext{
${ }^{6}$ See Memorandum to All Power Reactor Applicants and Licensees from Harold R. Denton, Director, NRC's Office of Nuclear Reactor Regulation, dated March 28, 1980, appended as Attachment 1 to Staff's Motion for Reconsideration, dated March 10, 1997.

${ }^{7}$ The NRC recently revised NUREG-1021 to replace the minimum passing grade of "80 percent" with " 80.00 percent." See NUREG-1021 (Interim Rev. 8), ES-401 at 39 of 39 (Form ES-401-7) and Appendix E at 1 of 5 (January 1997). But this revision does not support an implication that the former term permitted rounding and therefore needed correction. Rather, the revision was akin both to the clarifying regulatory amendments that this Commission and other agencies regularly promulgate and to the clarifying legislation that Congress regularly enacts. See, e.g., Final Rule, "Preparation, Transfer for Commercial Distribution, and Use of Byproduct Material for Medical Use," 59 Fed. Reg. 61,767, 61,776 (Dec. 2, 1994); Wong Yong Sung v. McGrath, 339 U.S. 33, 47, modified, 339 U.S. 908 (1950).

${ }^{8}$ Our research has identified several cases from around the country where the judiciary declined to disturb testing authorities' refusal to "round up" almost-passing scores. See Reilly v. Levitt, 1988 WL 49187 at *4 (S.D.N.Y. May 6, 1988); McIntosh v Borough of Manhattan Community College, 78 A.D.2d 839, 433 N.Y.S.2d 446, 447 (1st Dept. 1980), aff'd, 55 N.Y.2d 913, 915, 433 N.E.2d 1274, 1275, 449 N.Y.S.2d 26, 27 (1982); Marquez v. University of Washington, 32 Wash. App. 302, 309, 648 P.2d 94, 98 (1982). Similarly, another decision deferred to the testing authority's determination to follow a "rounding up" policy. See Ash v. Police Commissioner of Boston. 11 Mass. App. 650, 653, 418 N.E.2d 622, 624 (1981). This line of cases supports our view that the decision to "round up" or not is for the testing authorities, not the adjudicators, to make
} 
a. Verify alarms by checking containment sump level recorder and spent fuel level indication.

b. Sound the containment evacuation alarm.

c. Initiate containment ventilation isolation.

d. Initiate control room ventilation isolation.

All parties, including Mr. Tetrick, recognize that answer "b" is correct. Therefore, the only issue before us on appeal regarding Question 63 is whether Mr. Tetrick's answer of "a" is also correct. For the reasons set forth in both LBP97-2 and LBP-97-11, we conclude that answer " $\mathrm{a}$ " is incorrect. ${ }^{9}$ We therefore cannot use Mr. Tetrick's answer to Question 63 as a ground to affirm the Presiding Officer's result in this case.

\section{CONCLUSION}

We grant the Staff's petition for review and reverse the Presiding Officer's rulings in both LBP-97-2 and LBP-97-6 regarding the "rounding" of Mr. Tetrick's written examination score.

Commissioner Diaz disapproved this order.

IT IS SO ORDERED.

For the Commission

JOHN C. HOYLE

Secretary of the Commission

Dated at Rockville, Maryland,

this 7th day of August 1997.

\footnotetext{
${ }^{9}$ In remanding this issue to the Presiding Officer, we relied in large part on Mr. Hovey's May lst letter arguing that both " $a$ " and " $b$ " are adequate responses to Question 63. We therefore believe that a brief explanation is appropriate as to why we resolve the "Question 63" issue differently from Mr. Hovey. In our view, we agree with the Presiding Officer that Mr. Hovey bases his conclusion on the erroneous assumption that Question 63 asked for an immediate action in response to "an" annunciator alarm. The question instead asked for the immediate action in response to two annunciator alarms under the specific plant conditions specified in the question.
} 
Directors'

Decisions

Under

10 CFR 2.206

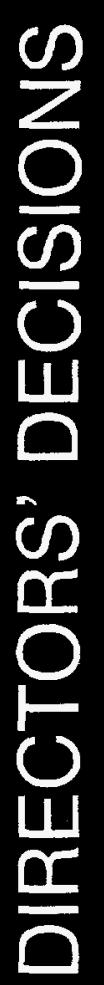


UNITED STATES OF AMERICA

NUCLEAR REGULATORY COMMISSION

\title{
OFFICE OF NUCLEAR REACTOR REGULATION
}

Samuel J. Collins, Director

In the Matter of

Docket Nos. 50-282

50-306

72-10

\author{
NORTHERN STATES POWER \\ COMPANY \\ (Prairie Island Nuclear Generating Plant; \\ Prairie Island Independent Spent Fuel \\ Storage Installation)
}

August 29, 1997

The Director of the Office of Nuclear Reactor Regulation denies a petition filed by the Prairie Island Indian Community pursuant to 10 C.F.R. $\$ 2.206$. The petition asked that the NRC: (1) find that the Licensee violated NRC regulations by using an Independent Spent Fuel Storage Installation before establishing conditions for safety unloading TN-40 dry storage containers, (2) suspend the license until all significant issues concerning the unloading process have been resolved, (3) provide the Petitioners with an opportunity to participate fully in reviewing the unloading procedures for the casks, and (4) update the relevant technical specifications to incorporate mandatory unloading procedure requirements for the $\mathrm{TN}-40$ dry storage containers.

\section{DIRECTOR'S DECISION UNDER 10 C.F.R. $\$ 2.206$}

\section{INTRODUCTION}

On May 28, 1997, the Prairie Island Indian Community filed a petition pursuant to section 2.206 of Title 10 of the Code of Federal Regulations (10 
C.F.R. § 2.206) requesting that the U.S. Nuclear Regulatory Commission (NRC) take action to accomplish the following:

1. Determine that Northern States Power (NSP) violated the requirements of 10 C.F.R. $\$ 72.122(l)$ by using its Materials License No. SNM-2506 for an Independent Spent Fuel Storage Installation (ISFSI) prior to establishing conditions for safely unloading the TN-40 dry storage containers;

2. Suspend Materials License No. SNM-2506 for cause under 10 C.F.R. $\$ 50.100$ until such time as all significant issues in the unloading process, as described herein [the petition], have been resolved, the unloading process has been demonstrated, and until an independent third-party review of the $\mathrm{TN}-40$ unloading procedure has been conducted;

3. Provide Petitioners an opportunity to participate fully in the reviewing of the unloading procedure for the TN-40 cask, hold hearings and allow Petitioners to participate fully in these and any other procedures initiated in response to this petition; and

4. Update the Technical Specifications (TS) for the Prairie Island ISFSI to incorporate mandatory unloading procedure requirements.

The petition has been referred to me pursuant to section 2.206. The NRC letter dated June 27, 1997, to Byron White, on behalf of the Petitioners, acknowledged receipt of the petition and provided the NRC Staff's determination that the petition did not require immediate action by the NRC. A notice of receipt was published in the Federal Register on July 3, 1997 (62 Fed. Reg. 36,085).

On the basis of the NRC Staff's evaluation of the issues and for the reasons given below, the Petitioners' requests are denied.

\section{BACKGROUND}

On October 19, 1993, the NRC issued Materials License No. SNM-2506 to NSP (the Licensee) to allow storage of spent nuclear fuel in TN-40 dry storage casks, designed by Transnuclear Incorporated, at the ISFSI located at the Prairie Island Nuclear Plant. No spent nuclear fuel was allowed to be loaded into a storage cask at Prairie Island until several preoperational license conditions were satisfied. Among the preoperational license conditions were a required training exercise (dry-run) of the loading, handling, and unloading activities for the TN-40 casks and the implementation of written procedures describing the actions to be taken during operation, off-normal, and emergency conditions associated with the Prairie Island ISFSI. The NRC issued TS defining operating limits, surveillance requirements, design features, and administrative controls as Appendix A to Materials License No. SNM-2506. 
A report dated April 20, 1995, submitted by the Licensee to the NRC pursuant to 10 C.F.R. $\$ 72.82(\mathrm{e})$, provided the results of the preoperational tests that were required to be performed by the Licensee before loading of spent fuel into a TN-40 cask. On May 11, 1995, the NRC granted a schedular exemption to the provision of section $72.82(\mathrm{e})$ that requires licensees to submit the preoperational test results at least 30 days before receipt of spent fuel into the ISFSI. The basis for the exemption was the fact that the NRC Staff had reviewed cask fabrication records, observed portions of the preoperational test activities as they occurred, and completed its review of the report submitted on April 20, 1995. On May 12, 1995, the Licensee began loading spent fuel assemblies into a TN-40 cask. The Licensee subsequently placed the cask, and casks loaded since that time, onto the storage pad within the Prairie Island ISFSI.

NRC regulations include a requirement that an ISFSI be designed to provide for the ready retrieval of spent fuel or high-level radioactive waste for further processing or disposal. This regulation, 10 C.F.R. $\$ 72.122(l)$, provides as follows:

Retrievability. Storage systems must be designed to allow ready retrieval of spent fuel or high-level radioactive waste for further processing or disposal.

Certain events or conditions could warrant removing a TN-40 cask from the Prairie Island ISFSI and returning it to the spent fuel pool and unloading the stored fuel assemblies. In addition to the regulatory requirements in section 72.122(l) pertaining to retrieval of the fuel assemblies for further processing or disposal, the TS for the Prairie Island ISFSI require the Licensee to take corrective actions in response to those design-basis events or conditions that may challenge the integrity of the storage cask or the cladding of the spent fuel assemblies. For example, section 2.3, "Maximum Cask Lifting Height," section 3/4.3, "Maximum Helium Leak Rate," and section 3/4.5, "Maximum Cask Surface Temperature," of the TS include provisions for unloading of a TN-40 storage cask in response to the specified events or conditions.

NRC regulations in 10 C.F.R. Part 72 require that the design of the storage system and the procedures implemented by specific licensees support the unloading activity, whether it is being performed to allow further processing or disposal of the spent fuel or it is required as part of the response to an unplanned event or condition, while preventing gross ruptures of the fuel cladding in order to prevent operational safety problems. Unloading procedures should also include contingencies in case fuel cladding has degraded during storage such that additional measures are necessary to address increased radiological hazards during the unloading process.

$\mathrm{NRC}$ regulations, facility licenses, and NRC-approved quality assurance programs require licensees to establish and maintain a formal process for the 
preparation and issuance of procedures and changes thereto. NRC assessments of licensee procedures are generally conducted as part of the NRC's inspection program. In this instance, the major procedures pertaining to dry cask storage activities at Prairie Island, including the procedure for unloading a cask, were reviewed by the NRC Staff during a special inspection conducted from January 24 through May 11, 1995. In addition to the review of the Licensee's facility and procedures, the NRC inspectors observed preoperational testing that the Licensee was required to perform before loading casks with spent fuel assemblies. The inspection findings are documented in NRC Inspection Report 50-282/95002, 50-306/95002, 72-10/95002(DRP), dated June 30, 1995.

The NRC inspectors identified several instances in which the procedures for dry cask storage activities that the Licensee had in place at the beginning of the inspection, including the procedures for loading and unloading of the TN-40 casks, did not ensure compliance with the requirements of the license. Although the inspectors were able to verify that the Licensee corrected the identified procedural deficiencies during the course of the inspection, a Notice of Violation was issued to the Licensee for failing to satisfy Criterion V of Appendix B to 10 C.F.R. Part 50, which, for activities affecting quality, requires the preparation and adherence to procedures appropriate to the circumstances. In addition, the inspectors identified weaknesses in the Licensee's initial performance in overseeing the activities of the cask vendor and in overall planning for dry cask storage activities. However, on the basis of the licensing reviews and inspection findings, documented in Inspection Report 50-282/95002, 50-306/95002, 7210/95002(DRP), the NRC Staff concluded that as of May 1995, the Licensee had corrected the identified deficiencies and was ready to safely load and, if necessary, unload spent nuclear fuel in TN-40 casks.

In July 1995, the NRC Staff issued an action plan for dry cask storage to manage the resolution of a variety of technical and process issues that were identified during the licensing reviews and inspections completed for the first several ISFSI facilities. An item related to the loading and unloading of dry storage casks was added to the action plan, in part to ensure that the importance of the unloading procedures was emphasized to licensees and technical issues related to unloading problems were resolved. Addition of an item pertaining to unloading was deemed prudent because the Staff observed that some unloading procedures implemented by licensees neglected to consider contingencies and assumptions related to possible fuel degradation, gas sampling techniques, cask design issues, radiation protection requirements, and the thermal-hydraulic behavior of a cask during the process of cooling and filling it with water from the spent fuel pool.

To implement the action plan, the NRC Staff formed a working group to identify issues associated with loading and unloading processes for dry storage casks and to propose means of informing the industry and the NRC Staff of those 
issues. The working group considered industry experiences, concerns identified during reviews and inspections, and other issues related to loading and unloading procedures. The working group completed its reviews in April 1996. The concerns related to unloading procedures reviewed by the working group were found to involve either (1) isolated occurrences that had been adequately resolved by site-specific corrective actions or (2) generic issues that were addressed by incorporating remedial measures into ongoing Staff activities, such as the preparation of revised inspection procedures or other guidance documents.

To fulfill some of the goals included in its dry cask storage action plan, the NRC Staff has emphasized the importance of unloading procedures and shared observations with licensees using or considering dry cask storage during opportunities such as the Spent Fuel Storage and Transportation Workshop held in May 1996 and meetings with individual licensees. The Staff revised inspection procedures to specifically instruct NRC inspectors to review unloading procedures developed by licensees and to identify those issues that warrant particular attention. Guidance included in NRC Inspection Procedure 60855, "Operation of an ISFSI," issued February 1, 1996, states:

For unloading activities, attention should be paid to how the licensee has prepared to deal with the potential hazards associated with that task. Some potential issues may include: the radiation exposure associated with drawing and analyzing a sample of the canister's potentially radioactive atmosphere; steam flashing and pressure control as water is added to the hot canister; and filtering or scrubbing the hot steam/gas mixture vented from the canister, as it is filled with water.

Similar guidance was included in NUREG-1536, "Standard Review Plan for Dry Cask Storage Systems," issued in January 1997. Application of the revised guidance ensures that recent and future reviews will address the adequacy of unloading procedures developed by licensees. The Staff also issued NRC Information Notice 97-51, "Problems Experienced with Loading and Unloading Spent Nuclear Fuel Storage and Transportation Casks," dated July 11, 1997, to inform licensees of operating experiences and problems encountered with the loading and unloading of storage and transportation casks for spent nuclear fuel.

To address those ISFSIs that began operation before the improvements in the NRC's review and inspection guidance, the Staff performed audits or inspections of those Licensee programs for which the inspection record did not document whether the unloading procedures adequately addressed the major issues included in the action plan. Regarding Prairie Island, the Staff reviewed the available information and determined that additional reviews or inspections were not necessary because the assessment of the unloading procedure performed as part of the inspection documented in NRC Inspection Report 50-282/95002, $50-306 / 95002,72-10 / 95002$ (DRP) adequately addressed the concerns included in the NRC action plan. 


\section{DISCUSSION}

The petition requests four actions by the NRC on the basis of the contention that the unloading procedure implemented by the Licensee was inadequate and, therefore, the Licensee violated the NRC regulation requiring it to have the ability to readily retrieve spent fuel or high-level radioactive waste for further processing or disposal.

\section{Item 1: Determine That the Licensee Violated Section 72.122(l)}

In support of the petition's contention that the Licensee violated NRC requirements, the Petitioners claim that the procedure to unload a TN-40 cask at Prairie Island has not been adequately evaluated or tested because neither the NRC nor NSP has completely demonstrated that a TN-40 dry cask can be unloaded after it has remained on the storage pad for a number of years. The Petitioners state that their request is supported by the fact that the preoperational test results for the Prairie Island ISFSI were submitted to the NRC on the day before the unloading procedure was approved by the Licensee's Operations Committee. The Petitioners also express concern that only portions of the Licensee's unloading procedure were tested during the required preoperational tests and, therefore, the tests did not provide assurance that an unloading can be done safely. In addition, the Petitioners state that procedures for unloading a cask should address specific concerns regarding failed fuel recovery and possible contamination of the spent fuel pool, venting of radioactive gases, functional checks of radiation monitoring and ventilation systems, and the buildup of steam when water is pumped into the cask as part of the unloading process.

As previously mentioned, cask designs and associated procedures are required to support the unloading of the spent fuel assemblies either to support further processing or disposal or in response to an unplanned event or condition that may challenge the integrity of the storage cask or the cladding of the spent fuel assemblies. Although the NRC Staff agrees with the Petitioners' premise that actually unloading a storage cask would likely result in licensees learning lessons that could result in additional enhancements to unloading procedures, the Staff does not agree that an actual demonstration of the unloading procedure at Prairie Island is warranted. In addition to the Staff's review of the procedure for unloading a TN-40 cask at Prairie Island, reasonable assurance that the TN-40 casks can be safely unloaded is provided by a variety of experiences related to the use and storage of radioactive materials. These experiences include the dry-run exercises that were performed to verify key aspects of unloading procedures for the TN-40 cask; related research sponsored by the commercial nuclear industry, the U.S. Department of Energy, and the NRC; actual loading and unloading of transportation casks; loading of storage casks; handling of spent fuel assemblies 
under various conditions; and performing relevant maintenance and engineering activities associated with reactor facilities.

Regarding the Petitioners' concerns pertaining to the dates of the submittal of preoperational tests and the approval of the Licensee's unloading procedure, the NRC Staff identified this discrepancy in Inspection Report 50-282/95002, 50-306/95002, 72-10/95002(DRP). The administrative controls included in the TS for the Prairie Island ISFSI require that the Operations Committee review and approve procedures and changes thereto. The approval of the Operations Committee is usually the last step in the process for preparing or revising a procedure. The fact that the Operations Committee approved the procedure shortly after submittal of the preoperational test results and before fuel loading satisfied the preoperational license condition to implement written procedures before loading spent nuclear fuel into a TN-40 cask. This matter does not, therefore, represent a violation of NRC requirements or introduce concerns pertaining to the technical adequacy of the unloading procedure.

The Petitioners identified several concerns pertaining to the lack of specific guidance in the unloading procedure to address a scenario in which significant fuel degradation occurs during storage. The NRC Staff agrees with the Petitioners that such a scenario would complicate the unloading process by requiring additional measures and precautions to limit the release of radioactive materials from the cask into parts of the reactor facility and nearby environs. The Licensee's unloading procedure includes a step to sample the atmosphere within the cask cavity to test for radioactive and flammable gases before venting the cask cavity and loosening the bolts securing the cask lid. Following the analysis of the gas sample, the Licensee's unloading procedure includes a hold point to allow personnel to determine whether additional steps or precautions are warranted. While acknowledging many of the Petitioners' legitimate concerns regarding the potential difficulties in retrieving failed fuel from dry storage casks, the NRC Staff has concluded that licensees need not be required to incorporate specific guidance into the normal unloading procedure to address this unlikely situation. The Staff's conclusion is based, in part, on the fact that the required compensatory actions and precautions needed to address such situations may vary significantly, depending on the actual results from the analysis of the gas sample. Requiring the Licensee to include contingencies or steps in the unloading procedure to address the unlikely event of failed fuel may unnecessarily complicate and delay the unloading of fuel assemblies that have remained intact during storage. On the basis of licensees' experiences in developing and implementing plans to address the problem of fuel assemblies damaged during reactor operations, in handling radioactive wastes of various forms, and in resolving other comparable problems, the NRC Staff has confidence that licensees could, if necessary, develop a plan to retrieve damaged fuel from a storage cask while minimizing the radiological consequences to 
plant workers and the general public. In addition to the general confidence of the NRC Staff that the technical problems associated with retrieving failed fuel could be overcome, requirements for planning and executing such an activity are contained in the licenses issued for the Prairie Island ISFSI and the Prairie Island Nuclear Generating Plant, and NRC regulations in 10 C.F.R. Parts 20, 50, and 72. The NRC Staff has, therefore, accepted gas sampling and defined hold or decision points before breaching the cask confinement boundary as an adequate means to address concerns pertaining to the unlikely degradation of fuel assemblies during storage.

The specific issues raised by the Petitioners to support their claim that the Licensee's unloading procedure is deficient are addressed below.

\section{a. Failed Fuel Considerations}

As previously discussed, the NRC Staff has accepted that procedures developed by licensees to support unloading of dry storage casks do not need to address the retrieval of failed fuel, provided that measures to detect possible fuel degradation and a defined hold point for determination of possible compensatory actions are appropriately placed within the subject procedures. As documented in NRC Inspection Report 50-282/95002, 50-306/95002, 72-10/95002(DRP), the Licensee had originally failed to incorporate a step in the unloading procedure for taking a gaseous sample from the cask in order to ensure that fuel degradation had not occurred during storage. However, in response to the findings of the NRC inspectors, the Licensee incorporated sampling of the cask atmosphere and a hold point for deliberation into the unloading procedure and the revised procedure was in place before spent nuclear fuel was loaded into a TN-40 cask. The NRC Staff has found that this action, in combination with the requirement that spent fuel assemblies loaded into TN-40 casks be free of gross cladding defects, provides reasonable assurance that the Licensee will not unknowingly breach the confinement boundary of a cask containing failed fuel. In the unlikely event that the gaseous sample indicates that spent fuel assemblies have degraded during storage, the unloading procedure instructs the Licensee's Operations Committee to add steps or precautions to the procedure in order to minimize the radiological consequences of retrieving the failed fuel. The NRC Staff has found this approach to be acceptable and does not require the Licensee's normal unloading procedure to include contingency actions to address the possible release of radioactive materials to parts of the reactor facility, including the spent fuel pool, that may occur if fuel assemblies degrade during storage. The NRC Staff believes, however, that the Petitioners have identified valid concerns regarding the potential recovery of fuel assemblies that have unexpectedly degraded during storage. As previously mentioned, the Staff believes that the regulations and licenses issued by the NRC require the Licensee to address these and other 
problems that may occur in the unlikely event that fuel assemblies that have degraded during storage need to be unloaded from dry storage casks.

\section{b. Venting of Radioactive Gases}

The possible need to vent radioactive gases from a cask is among the issues that the Licensee would need to address if the required sampling of the atmosphere within a cask indicates that the spent fuel assemblies have experienced unanticipated degradation during storage. As with the concern regarding the contamination of the spent fuel pool, the need to vent the cask while minimizing the radiological consequences of unloading a cask containing failed fuel is an issue that the Licensee would need to address before revising the procedure and proceeding with the unloading process. In addition to ensuring that the unloading activity results in occupational doses and doses to members of the public that are as low as is reasonably achievable (see 10 C.F.R. $\$ 20.1101$ ), the Licensee would need to perform the venting of a cask containing failed fuel in accordance with the Prairie Island Nuclear Generating Plant Facility Operating Licenses, associated TS, and applicable regulations.

\section{c. Radiation Monitors}

The Petitioners contend that the unloading procedure must include a "stopcheck" to verify that ventilation systems and radiation monitors are functioning before the venting of a cask is performed. Although agreeing with the Petitioners' general premise that prerequisites to preforming procedures should include establishing confidence in the tools and equipment being used, the NRC Staff notes that during the anticipated unloading of spent nuclear fuel that has not degraded during storage, special ventilation or radiation monitoring equipment beyond that specified in the Licensee's unloading procedure and radiation protection program is not required. The unloading procedure requires the involvement of radiation protection personnel and the activity must be controlled in accordance with the Licensee's radiation protection program, which includes provisions for the maintenance and calibration of radiation detectors. Although the venting process is not expected to need ventilation systems equipped with filters and radiation monitors, the spent fuel pool special ventilation system could be used if necessary. The spent fuel pool special ventilation system is required to be operable during subsequent steps in the procedure if spent fuel assemblies are being moved and the system must be tested and maintained in accordance with the TS for the Prairie Island Nuclear Generating Plant. In the unlikely event that the Licensee needs to unload a cask containing degraded fuel assemblies, confirming the operability of those ventilation systems and additional radiation 
monitoring equipment being used to minimize the release of radioactive materials is an activity that the Licensee would need to address before revising the procedure and proceeding with the unloading process.

\section{d. Steam Buildup}

The Petitioners expressed concerns regarding the reaction of the cask and stored fuel assemblies to the introduction of spent fuel pool water during the execution of the unloading procedure. The unloading procedure includes the partial immersion of the $\mathrm{TN}-40$ cask into the spent fuel pool, connection of hoses to the vent and drain connections, and the slow introduction of spent fuel pool water to the cask cavity and stored fuel assemblies. The procedure instructs personnel to continuously monitor the temperature and pressure instrumentation installed on the vent connection and to stop pumping water if the pressure exceeds 10 psig or the temperature exceeds $240^{\circ} \mathrm{F}$. In the Staff's judgment, the cooling process imposed by these limitations on temperatures and pressures at the vent port of the cask will adequately ensure that the cooling of the cask and spent fuel is gradual and, thereby, prevent safety problems that could hypothetically result from damage to the cask or the fuel assemblies because of stresses induced by a poorly controlled addition of cooling water from the spent fuel pool.

The Petitioners expressed concerns pertaining to the range of the instrumentation used during the venting of a TN-40 cask and stated that higher ranges for temperature and pressure are necessary. The instrumentation ranges specified in the unloading procedure's drawing of the cask vent port adapter are $50-300^{\circ} \mathrm{F}$ for temperature and 0-30 psig for pressure. While not judging if these are the optimum ranges for the instrumentation, the NRC Staff finds that the ranges are adequate to support the administrative limits of $240^{\circ} \mathrm{F}$ and $10 \mathrm{psig}$ established in the procedure and the related response action of stopping the addition of water to the cask if these administrative limits are exceeded. Regarding the Petitioners' concern regarding the need to post hazard warnings during the refilling of a cask, the unloading procedure does include several notes and precautions to remind personnel that the fluid exiting the vent port may present radiological and thermal hazards.

In summary, many of the Petitioners' concerns pertain to potential problems with unloading spent fuel from a TN-40 cask if the fuel cladding has degraded during storage. While acknowledging that such concerns regarding the potential difficulties in retrieving failed fuel from dry storage casks are legitimate, the NRC Staff has concluded that licensees need not be required to incorporate specific guidance into the normal unloading procedure to address this unlikely situation. On the basis of its review of the information provided by the Petitioners and its reviews of the Licensee's procedure for unloading TN-40 
casks at Prairie Island, the NRC Staff has not identified violations of section $72.122(l)$ or other regulatory requirements pertaining to the content or quality of the Licensee's unloading procedure.

\section{Item 2: Suspend Materials License No. SNM-2506}

On the basis of the contention that the Licensee's unloading procedure was inadequate, the Petitioners requested that Materials License No. SNM-2506 be suspended until such time as the significant issues in the unloading process have been resolved, the unloading process has been demonstrated, and an independent third-party review of the TN-40 unloading procedure has been conducted. ${ }^{1}$

As previously stated, the NRC Staff has performed a review of the procedure for unloading a TN-40 cask at Prairie Island. The review, including verification that the Licensee's unloading procedure was revised to address deficiencies identified by the NRC inspectors, is documented in NRC Inspection Report 50282/95002, 50-306/95002, 72-10/95002(DRP). The review performed during the NRC inspection, subsequent evaluations performed by the NRC Staff as part of the activities associated with the dry cask storage action plan and the review of this petition, and the required control of the procedure in accordance with Licensee programs developed in accordance with NRC regulations, facility licenses, and NRC-approved quality assurance programs provide reasonable confidence that the Licensee could, if necessary, safely unload a TN-40 cask.

Regarding a third-party review, the NRC Staff's concern about the quality of licensees' unloading procedures led it to include the issue in the dry cask storage action plan. The action plan provided a framework for the identification and resolution of various technical and administrative issues related to the use of dry storage casks. The previously mentioned actions taken by the NRC Staff and licensees adequately resolved the identified issues pertaining to cask unloading procedures. In the specific case of the unloading procedure at Prairie Island, the Licensee revised the procedure to address the problems identified by the Staff during its inspection. On the basis of the actions it has already taken, the NRC Staff does not believe that the situation warrants additional review of the Licensee's unloading procedure by an independent third party.

\footnotetext{
${ }^{1}$ The Petitioners request that Materials License No. SNM-2506 be suspended for cause in accordance with 10 C.F.R. $\$ 50.100$. Provisions for the modification, revocation, or suspension of the licenses for ISFSI facilities are contained in 10 C.F.R. $\$ 72.60$. The possible reasons for suspending licenses for ISFSIs in accordance with section 72.60 are similar to the corresponding reasons for suspending licenses for production and utilization facilities in accordance with section 50.100 .
} 
Item 3: Allow Petitioners to Review Procedure, and for NRC to Hold Hearings and Allow Petitioners to Participate in the Proceedings

The Licensee has provided the NRC with the unloading procedure, including Revision 2, dated November 8, 1996, for placement into the public record, and the Petitioners have been supplied with or have obtained copies of the procedure from the NRC's document control system. Accordingly, Petitioners have had the opportunity to review a recent revision of the unloading procedure. For the reasons previously discussed in this Decision, the NRC Staff sees no teason to undertake additional reviews of the procedure or to initiate a formal proceeding in which the Petitioners could participate. Although the NRC has decided not to initiate a hearing in response to this petition, the Petitioners are encouraged to continue their interactions with the NRC Staff regarding concerns or questions about the operation of the Prairie Island Nuclear Generating Plant or the Prairie Island ISFSI.

\section{Item 4: Update the Technical Specifications for the Prairie Island ISFSI to Incorporate Mandatory Unloading Procedure Requirements}

The TS for ISFSIs are required by 10 C.F.R. $\$ 72.44$ to include requirements in the following categories:

(1) Functional and operating limits and monitoring instruments and limiting control settings;

(2) Limiting conditions;

(3) Surveillance requirements;

(4) Design features; and

(5) Administrative controls.

Although the TS for the Prairie Island ISFSI requires that TN-40 casks be unloaded if certain events or conditions defined in the TS are satisfied, the TS do not include specific requirements for the unloading process. The content of the TS for the Prairie Island ISFSI is typical in this respect since neither section 72.44 nor the associated regulatory guidance documents specify that technical specifications should include special requirements for the unloading procedure. ${ }^{2}$ Instead, the functional and operating limits, limiting conditions, administrative controls, and other requirements included in the TS for the Prairie

\footnotetext{
${ }^{2}$ Recent NRC staff guidance pertaining to the appropriate content of technical specifications is provided in NUREG-1536, "Standard Review Plan for Dry Cask Storage Systems," published in January 1997. Similar guidance is provided by NRC Regulatory Guide 3.61, "Standard Format and Content for a Topical Safety Analysis Report for' a Spent Fuel Dry Storage Cask," issued in February 1989, and NRC Regulatory Guide 3.48, "Standard Format and Content for the Safety Analysis Report for an Independent Spent Fuel Storage Installation (Dry Storage)," issued in October 1981
} 
Island ISFSI are intended to maintain the cask and stored spent fuel assemblies within the limits established for safe operation during storage within the ISFSI and activities such as loading and unloading of the casks. For example TS 2.3 limits the allowable lifting heights during movement of the cask from the ISFSI and TS 3/4.2 requires a measurement of the boron concentration of the water in the spent fuel pool before water is introduced to the cask during the unloading process.

The absence of specific requirements in the TS to control the unloading process does not diminish the importance that the NRC Staff places on this activity or the validity of the Petitioners' concerns. The NRC Staff believes that other regulatory requirements provide an equivalent level of protection to the Petitioners' request to include specific requirements in the TS to control the unloading of a TN-40 cask. The administrative controls in the TS for the Prairie Island ISFSI require that the associated procedures, including the unloading procedure, be prepared, reviewed, and maintained in accordance with the requirements of the Prairie Island Nuclear Generating Plant Facility Operating Licenses and associated TS. In addition, under existing NRC requirements, the Licensee must adequately implement procedures to control loading, maintaining, and unloading of dry storage casks (see 10 C.F.R. $\$ \$ 72.122,72.150$, and 72.152). For example, the NRC inspection documented in Inspection Report 50-282/95002, 50-306/95002, 72-10/95002(DRP) resulted in a Notice of Violation issued to the Licensee because the Licensee failed to satisfy the NRC's requirements in Criterion V of Appendix B to 10 C.F.R. Part 50 by not having incorporated appropriate steps and precautions into the original procedure developed to control unloading of a TN-40 cask. As demonstrated by the example, no changes to the TS or the Safety Analysis Report (SAR) are needed to ensure that enforceable operating controls and limits are in place to address the unloading of a cask.

In regard to another concern raised by the Petitioners, the Prairie Island ISFSI SAR and other docketed correspondence do state that unloading a TN-40 cask would be performed using a procedure that is basically the reverse of the procedure used to load the cask. Although this statement, in a general sense, is true, the NRC Staff agrees with the Petitioners that such statements may be misleading in that they oversimplify the description of the unloading activity. For this reason, the NRC Staff included an item related to unloading procedures in its dry cask storage action plan to ensure that actual unloading procedures did not reflect such an oversimplified representation. The unloading procedure for the dry storage casks at Prairie Island was inspected by the NRC Staff and, as previously discussed, was ultimately found to provide adequate guidance to control the unloading process. 


\section{CONCLUSION}

For the reasons described above, the NRC has determined that no adequate basis exists for granting the Petitioners' request for suspension of Northern States Power Company's license for dry cask storage of spent nuclear fuel at Prairie Island or for taking the other actions requested by the Petitioners. While acknowledging that the Petitioners' concerns regarding the potential difficulties in retrieving failed fuel from dry storage casks are legitimate, the NRC Staff has concluded that licensees need not be required to incorporate specific guidance into the normal unloading procedure to address this unlikely situation.

A copy of this Decision will be filed with the Secretary of the Commission for the Commission to review in accordance with 10 C.F.R. $\$ 2.206$ (c).

As provided by this regulation, this Decision will constitute the final action of the Commission 25 days after issuance, unless the Commission, on its own motion, institutes a review of the Decision within that time.

\section{FOR THE NUCLEAR REGULATORY COMMISSION}

Samuel J. Collins, Director

Office of Nuclear Reactor

Regulation

Dated at Rockville, Maryland,

this 29th day of August 1997. 